\title{
Stress analysis of laminated composite and soft core sandwich beams using a simple higher order shear deformation theory
}

\author{
A. S. Sayyad ${ }^{1 *}$ Y. M. Ghugal ${ }^{2}$ and P. N. Shinde ${ }^{1}$ \\ ${ }^{1}$ Department of Civil Engineering, SRES's College of Engineering, Savitribai Phule Pune \\ University, Kopargaon-423601, Maharashtra, India \\ Email: attu_sayyad@yahoo.co.in \\ ${ }^{2}$ Department of Applied Mechanics, Government Engineering College, Karad-415124, \\ Maharashtra, India, \\ Email: ghugal@rediffmail.com \\ ${ }^{1}$ Department of Civil Engineering, SRES’s College of Engineering, Savitribai Phule Pune \\ University, Kopargaon-423601, Maharashtra, India \\ Email: Pratap_60@yahoo.co.in \\ *Corresponding author
}

\begin{abstract}
In this paper, the refined beam theory (RBT) is examined for the bending of simply supported isotropic, laminated composite and sandwich beams. The axial displacement field uses parabolic function in terms of thickness ordinate to include the effect of transverse shear deformation. The transverse displacement consists of bending and shear components. The present theory satisfies the traction free conditions on the upper and lower surfaces of the beam without using problem dependent shear correction factors of Timoshenko. Governing differential equations and boundary conditions associated with the assumed displacement field are obtained by using the principle of virtual work. To prove the credibility of the present theory, we applied it to the bending analysis of beams. A simply supported isotropic, laminated composite and sandwich beams are analyzed using Navier approach. The numerical results of non-dimensional displacements and stresses obtained by using the present theory are presented and compared with those of other refined theories available in the literature along with the elasticity solution.
\end{abstract}

Keywords: transverse shear deformation, shear correction factor, transverse shear stress, bending, laminated composite, sandwich.

\section{Introduction}

Structural components made of fibrous composite materials are increasingly being used in various engineering applications due to their attractive properties in strength, stiffness, and lightness. The effect of transverse shear deformation is more pronounced in thick beams made of fibrous composite material which has a high extensional modulus to shear modulus ratio.

The classical beam theory (CBT) does not predict the correct bending behaviour of thick beams made of fibrous composite materials. The first order shear deformation beam theory (FSDT) developed by Timoshenko (1921) includes the effect of transverse shear deformation but 
does not satisfy the zero shear stress conditions on the top and bottom surfaces of the beam, hence, it requires shear correction factor. Many higher order theories are available in the literature for the bending, buckling and free vibration analysis of laminated composite beams which take into account the effect of transverse shear deformation and do not require shear correction factor. The third order theory of Reddy (1984) is the most commonly used higher order theory for beams as well as for plates. A recent review of higher order theories available for the analysis of laminated composite beams has been presented by Ghugal and Shimpi (2001). Kadoli et al. (2008) applied the third order theory of Reddy for the static analysis of functionally graded beams. A general analytical model was developed by Lee (2005) using the shear deformable beam theory and was applied to the flexural analysis of thin walled I-shaped laminated composite beams. Chen and Wu (2005) developed a new higher-order shear deformation theory based on global-local superposition technique. Reddy (2007) reformulated various beam theories using nonlocal elasticity and applied them to the bending, buckling and vibration analysis of beams. Wang et al. (2008) also presented some work on beam bending solutions based on nonlocal Timoshenko beam theory. Mechab et al. (2008) carried out an assessment of parabolic and exponential shear deformation theories on bending of short laminated composite beams subjected to mechanical and thermal loadings. Carrera and Giunta (2010) presented refined beam theories based on a unified formulation and applied them to the static analysis of beams made of isotropic materials. Karama et al. (2008) did the refinement of Ambartsumian multi-layer beam theory considering an exponential function in terms of thickness coordinate. Chakrabarti et al. (2011) presented a new finite element model based on the zig-zag theory for the analysis of sandwich beams which is further extended by Chalak et al. (2011) for free vibration analysis of laminated sandwich beams having soft core. Gherlone et al. (2011) carried out the finite element analysis of multilayered composite and sandwich beams based on the refined zigzag theory. Sayyad and Ghugal (2011) developed a trigonometric shear and normal deformation theory for the bending analysis of laminated composite beams subjected to various static loadings. Sayyad (2011) presented a refined shear deformation theory for the static flexure and free vibration analysis of thick isotropic beams considering parabolic, trigonometric, hyperbolic and exponential functions in terms of thickness co-ordinate associated with transverse shear deformation effect. This theory is further extended by Sayyad et al. (2014) for the flexural analysis of single layered composite beams. Chen et al. (2011) carried out bending analysis of laminated composite plates considering first order shear deformation based on modified couple stress theory. Aguiar et al. (2012) carried out static analysis of composite beams of different cross-sections using mixed and displacement based models. Ghugal and Shinde (2013) extended the layerwise trigonometric shear deformation theory of Shimpi and Ghugal (2001) for the bending analysis of two layered anti-symmetric laminated composite beams with various boundary conditions. Recently, Sayyad et al. (2015) developed a new trigonometric shear deformation theory for the bending analysis of laminated composite and sandwich beams.

The theory used in the present study is originally developed by Shimpi and Patel (2006) for the bending analysis of orthotropic plates. In this paper, this theory is applied to the bending analysis of laminated composite and sandwich beams. Governing equations and boundary conditions of the presented theory are obtained using the principle of virtual work. The Navier's solution technique is employed for the simply supported boundary conditions. The numerical results are obtained for isotropic, laminated composite and sandwich beams subjected to sinusoidal load.

\section{The development of the theory}

A laminated composite beam of length ' $L$ ', width ' $b$ ' and overall thickness ' $h$ ' as shown in Fig. 1 is considered. The beam consists of ' $N$ ' number of layers made up of linearly elastic orthotropic 
material. The beam occupies the region $0 \leq x \leq L,-b / 2 \leq y \leq b / 2$ and $-h / 2 \leq z \leq h / 2$ in Cartesian coordinate system.

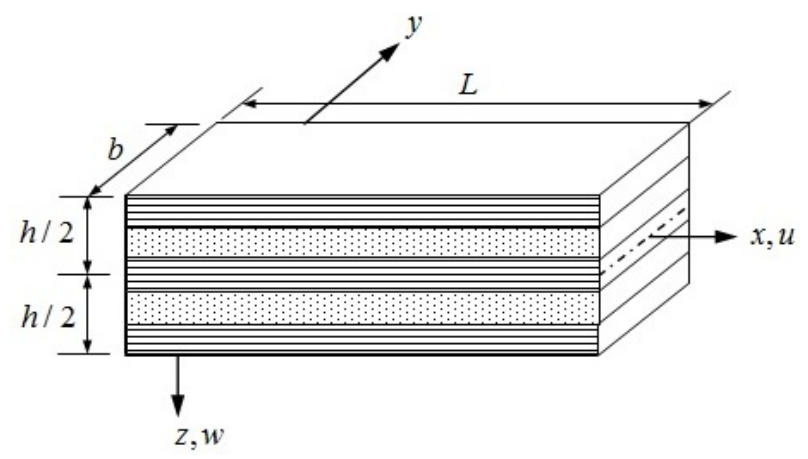

Fig. 1. Geometry and coordinate system of laminated composite beam.

In the present theory, the axial displacement $u$ in $x$ direction consists of extension, bending and shear components, whereas transverse displacement $w$ in the $z$-direction consists of bending $\left(w_{b}\right)$ and shear $\left(w_{\mathrm{s}}\right)$ components along the center line of the beam:

$$
\begin{gathered}
u(x, z)=u_{0}(x)-z \frac{d w_{b}(x)}{d x}-\left[\frac{5}{3} \frac{z^{3}}{h^{2}}-\frac{z}{4}\right] \frac{d w_{s}(x)}{d x} \\
w=w_{b}(x)+w_{s}(x)
\end{gathered}
$$

where $u_{0}$ is the axial displacement along the center line of the beam. The nonzero strain components corresponding to the assumed displacement field are as follows:

$$
\varepsilon_{x}=\varepsilon_{x}^{0}+z k_{x}^{b}+f(z) k_{x}^{s} \quad \text { and } \quad \gamma_{z x}=\gamma_{z x}^{0} g(z)
$$

where

$$
\varepsilon_{x}^{0}=\frac{d u_{0}}{d x}, \quad k_{x}^{b}=-\frac{d^{2} w_{b}}{d x^{2}}, \quad k_{x}^{s}=-\frac{d^{2} w_{s}}{d x^{2}}, \quad \gamma_{z x}^{0}=\frac{d w_{s}}{d x}, \quad f(z)=\left[\frac{5}{3} \frac{z^{3}}{h^{2}}-\frac{z}{4}\right] \quad \text { and } \quad g(z)=\left[\frac{5}{4}-5 \frac{z^{2}}{h^{2}}\right]
$$

The stress strain relationship for $k^{\text {th }}$ layer of laminated composite beam is as follows:

$$
\sigma_{x}^{k}=Q_{11}^{k} \varepsilon_{x}^{k} \text { and } \tau_{z x}^{k}=Q_{55}^{k} \gamma_{x z}^{k}
$$

where $Q_{11}^{k}$ is the Young's modulus in the axial direction of the laminated composite beam, while $Q_{55}^{k}$ is the shear modulus. The principle of virtual work is used to obtain the governing equations of equilibrium and associate boundary conditions. The analytical form of the Principle of virtual work is:

$$
b \int_{0}^{L} \int_{-h / 2}^{h / 2}\left(\sigma_{x} \delta \varepsilon_{x}+\tau_{z x} \delta \gamma_{x z}\right) d x d z-b \int_{0}^{L} q\left(\delta w_{b}+\delta w_{s}\right) d x=0
$$

Substituting expressions for strains and stresses from Eqs. (3) - (5) into Eq. (6), the principle of virtual work can be rewritten as: 


$$
\int_{0}^{L}\left(N_{x} \frac{d \delta u_{0}}{d x}-M_{x}^{b} \frac{d^{2} \delta w_{b}}{d x^{2}}-M_{x}^{s} \frac{d^{2} \delta w_{s}}{d x^{2}}+Q_{x} \frac{d \delta w_{s}}{d x}\right) d x-\int_{0}^{L} q\left(\delta w_{b}+\delta w_{s}\right) d x=0
$$

where $\delta$ is the variational operator. The stress resultants $\left(N_{x}, M_{x}^{b}, M_{x}^{s}, Q_{x}\right)$ associated with the assumed displacement field are defined as:

$$
\left\{\begin{array}{lll}
N_{x} & M_{x}^{b} & M_{x}^{s}
\end{array}\right\}=\sum_{k=1}^{N} \int_{-h / 2}^{h / 2}\left\{\begin{array}{lll}
1 & z & f(z)
\end{array}\right\} \sigma_{x}^{k} d z, \quad Q_{x}=\sum_{k=1}^{N} \int_{-h / 2}^{h / 2} \tau_{x z}^{k} g(z) d z
$$

Substituting stresses from Eq. (5) into the Eq. (8) and integrating through the thickness, the following equations are obtained:

$$
\begin{gathered}
N_{x}=A_{11} \frac{d u_{0}}{d x}-B_{11} \frac{d^{2} w_{b}}{d x^{2}}-C_{11} \frac{d^{2} w_{s}}{d x^{2}} \\
M_{x}^{b}=B_{11} \frac{d u_{0}}{d x}-D_{11} \frac{d^{2} w_{b}}{d x^{2}}-E_{11} \frac{d^{2} w_{s}}{d x^{2}} \\
M_{x}^{s}=C_{11} \frac{d u_{0}}{d x}-E_{11} \frac{d^{2} w_{b}}{d x^{2}}-F_{11} \frac{d^{2} w_{s}}{d x^{2}} \\
Q_{x}=G_{55} \frac{d w_{s}}{d x}
\end{gathered}
$$

Integrating Eq. (7) by parts and setting the coefficients of $\delta u_{0}, \delta w_{b}, \delta w_{s}$ zero, the following governing differential equations and associated boundary conditions are obtained:

$$
\begin{aligned}
& \delta u_{0}: \frac{d N_{x}}{d x}=0 \\
& \delta w_{b}: \frac{d^{2} M_{x}^{b}}{d x^{2}}+q=0 \\
& \delta w_{s}: \frac{d^{2} M_{x}^{s}}{d x^{2}}+\frac{d Q_{x}}{d x}+q=0
\end{aligned}
$$

The boundary conditions of the present theory at $x=0, x=L$ are of the form:

$$
\begin{array}{llll}
\text { Specify } & N_{x} & \text { or } & u_{0} \\
\text { Specify } & \frac{d M_{x}^{b}}{d x} & \text { or } & w_{b} \\
\text { Specify } & M_{x}^{b} & \text { or } & \frac{d w_{b}}{d x} \\
\text { Specify } & \frac{d M_{x}^{s}}{d x} & \text { or } & w_{s} \\
\text { Specify } & M_{x}^{s} & \text { or } & \frac{d w_{s}}{d x}
\end{array}
$$

The governing differential equations in terms of unknown displacement variables $\left(u_{0}, w_{b}, w_{s}\right)$ are rewritten as: 


$$
\begin{gathered}
\delta u_{0}: \quad-A_{11} \frac{d^{2} u_{0}}{d x^{2}}+B_{11} \frac{d^{3} w_{b}}{d x^{3}}+C_{11} \frac{d^{3} w_{s}}{d x^{3}}=0 \\
\delta w_{b}: \quad-B_{11} \frac{d^{3} u_{0}}{d x^{3}}+D_{11} \frac{d^{4} w_{b}}{d x^{4}}+E_{11} \frac{d^{4} w_{s}}{d x^{4}}=q \\
\delta w_{s}: \quad-C_{11} \frac{d^{3} u_{0}}{d x^{3}}+E_{11} \frac{d^{4} w_{b}}{d x^{4}}+F_{11} \frac{d^{4} w_{s}}{d x^{4}}-G_{55} \frac{d^{2} w_{s}}{d x^{2}}=q
\end{gathered}
$$

where

$$
\begin{aligned}
& A_{11}=\sum_{k=1}^{N} Q_{11}^{k} \int_{-h / 2}^{h / 2} d z, \quad B_{11}=\sum_{k=1}^{N} Q_{11}^{k} \int_{-h / 2}^{h / 2} z d z, \quad C_{11}=\sum_{k=1}^{N} Q_{11}^{k} \int_{-h / 2}^{h / 2} f(z) d z, \\
& D_{11}=\sum_{k=1}^{N} Q_{11}^{k} \int_{-h / 2}^{h / 2} z^{2} d z, \quad E_{11}=\sum_{k=1}^{N} Q_{11}^{k} \int_{-h / 2}^{h / 2} z f(z) d z, \\
& F_{11}=\sum_{k=1}^{N} Q_{11}^{k} \int_{-h / 2}^{h / 2}[f(z)]^{2} d z, \quad G_{55}=\sum_{k=1}^{N} Q_{55}^{k} \int_{-h / 2}^{h / 2}[g(z)]^{2} d z
\end{aligned}
$$

\subsection{The Navier solution for simply supported beams}

The closed form solution is obtained using the Navier's solution technique. A beam as shown in Fig. 1 is considered for the detailed numerical study. The following simply-supported boundary conditions are considered at $x=0, x=L$

$$
N_{x}=w_{b}=w_{s}=M_{x}^{b}=M_{x}^{s}=0
$$

The beam is subjected to sinusoidal load $q(x)$ on the top surface, i.e. $z=-h / 2$. The load $q$ is expanded in single trigonometric series:

$$
q(x)=q_{0} \sin \frac{\pi x}{L}
$$

where $q_{0}$ denotes the intensity of the load at the center of the beam. The following expansions of the unknown displacement variables $\left(u_{0}, w_{b}, w_{s}\right)$ satisfy the boundary conditions in Eq. (19):

$$
u_{0}=u_{1} \cos \frac{\pi x}{L}, \quad w_{b}=w_{b 1} \sin \frac{\pi x}{L}, \quad w_{s}=w_{s 1} \sin \frac{\pi x}{L}
$$

where $u_{1}, w_{b 1}, w_{s 1}$ are arbitrary parameters. Substituting unknown displacement variables ( $u_{0}, w_{b}, w_{s}$ ) from Eq. (21) and the load from Eq. (20) into the Eqs. (15) - (17), the closed-form solutions can be obtained from the following equations:

$$
\left[\begin{array}{lll}
K_{11} & K_{12} & K_{13} \\
K_{12} & K_{22} & K_{23} \\
K_{13} & K_{23} & K_{33}
\end{array}\right]\left\{\begin{array}{l}
u_{1} \\
w_{b 1} \\
w_{s 1}
\end{array}\right\}=\left\{\begin{array}{c}
0 \\
q_{0} \\
q_{0}
\end{array}\right\}
$$

where 


$$
\begin{aligned}
& K_{11}=A_{11} \frac{\pi^{2}}{L^{2}}, \quad K_{12}=-B_{11} \frac{\pi^{3}}{L^{3}}, \quad K_{13}=-C_{11} \frac{\pi^{3}}{L^{3}}, \\
& K_{22}=D_{11} \frac{\pi^{4}}{L^{4}}, \quad K_{23}=E_{11} \frac{\pi^{4}}{L^{4}}, \quad K_{33}=F_{11} \frac{\pi^{4}}{L^{4}}+G_{55} \frac{\pi^{2}}{L^{2}}
\end{aligned}
$$

\section{Numerical results and discussion}

To assess the efficiency of the present theory, the bending analysis of simply supported beams is considered. The numerical results are obtained for displacements and stresses for isotropic, laminated composite and sandwich beams. The values of transverse shear stress $\left(\tau_{z x}\right)$ presented in the tables are obtained by using equilibrium equations of the theory of elasticity to satisfy interface continuity.

$$
\tau_{z x}=\sum_{k=1}^{N} \int_{-h / 2}^{h / 2} \frac{d \sigma_{x}}{d x} d z
$$

The following non-dimensional forms are used to present the displacements and stresses:

$$
\begin{aligned}
& \bar{u}(0,-h / 2)=u \times n_{1}, \quad \bar{w}(L / 2,0)=w \times n_{2}, \\
& \bar{\sigma}_{x}(0,-h / 2)=\sigma_{x} \times n_{3}, \quad \bar{\tau}_{z x}(0,0)=\tau_{z x} \times n_{3}
\end{aligned}
$$

where

$$
n_{1}=\frac{b}{100 q_{0} h}, \quad n_{2}=\frac{100 h^{3}}{q_{0} a^{4}}, \quad n_{3}=\frac{b}{10 q_{0}}
$$

\subsection{Bending analysis of isotropic beams}

The simply supported isotropic beams subjected to sinusoidal load are considered with the following material properties:

$$
Q_{11}=210 \mathrm{GPa} \text { and } Q_{55}=80.77 \mathrm{GPa}
$$

Table 1 shows the maximum displacements and stresses for the simply supported isotropic beams with $L / h=4,10,20,50$ and 100 . The present results are compared with the elasticity solution provided by Ghugal (2006), the higher order shear deformation theory (HSDT) of Reddy (1984), the first order shear deformation theory (FSDT) of Timoshenko (1921) and the classical beam theory (CBT). From the examination of Table 1 it is observed that the present theory accurately predicts the values of axial $(\bar{u})$ and transverse $(\bar{w})$ displacements. For $L / h=4,10$ and 20, these displacements ( $\bar{u}$ and $\bar{w}$ ) are identical to those obtained by the HSDT of Reddy (1984). The bending stress predicted by the present theory is in excellent agreement with that of the exact solution. It is also observed that the transverse shear stress $\left(\bar{\tau}_{z x}\right)$ evaluated by using equilibrium equations is close to elasticity solution.

\subsection{Bending analysis of two layered $\left(0^{\circ} / 90^{\circ}\right)$ laminated composite beams}

The two layered anti-symmetric cross-ply laminated composite beams with simply supported boundary conditions and subjected to sinusoidal load with following material properties are considered. 


$$
\begin{gathered}
0^{0} \text { layer }(z=-h / 2 \text { to } z=0): Q_{11}=25 \text { and } Q_{55}=0.5 \\
90^{0} \text { layer }(z=0 \text { to } z=h / 2): Q_{11}=1.0 \text { and } Q_{55}=0.2
\end{gathered}
$$

The layers are of equal thickness i.e. $h / 2$. The displacements and stresses are obtained for different $L / h$ ratios such as $4,10,20,50$ and 100. The numerical results are reported in Table 2 . From Table 2 it is observed that, even for thick beams, the displacements and stresses obtained using the present theory are in excellent agreement with those obtained by the HSDT of Reddy (1984) and the 3-D elasticity solution given by Pagano (1969). The transverse shear stress continuity is maintained via equilibrium equations of theory of elasticity. The CBT underestimates the values of displacements and bending stress whereas it overestimates the values of transverse shear stress due to the neglect of transverse shear deformation. The variations of axial displacement, bending stress and transverse shear stress with respect to thickness ordinate are shown in Fig. 2 through Fig. 4.

\subsection{Bending analysis of three layered $\left(0^{\circ} / 90^{\circ} / 0^{\circ}\right)$ laminated composite beams}

A simply supported three layered symmetric cross-ply laminated composite beam under sinusoidal load is considered with the following material properties.

$$
\begin{gathered}
0^{0} \text { layer }(z=-h / 2 \text { to } z=-h / 6): Q_{11}=25 \text { and } Q_{55}=0.5 \\
90^{0} \text { layer }(z=-h / 6 \text { to } z=h / 6): Q_{11}=1.0 \text { and } Q_{55}=0.2 \\
0^{0} \text { layer }(z=h / 6 \text { to } z=h / 2): Q_{11}=25 \text { and } Q_{55}=0.5
\end{gathered}
$$

The layers are of equal thickness i.e. $h / 3$. The displacements and stresses for the beam with above material properties are presented in Table 3. The numerical results are compared with the HSDT of Reddy (1984), the FSDT of Timoshenko (1921), the CBT and exact elasticity solution given by Pagano (1969). Comparing the results with other theories, it is observed that, axial displacement predicted by the present theory and the theory of Reddy is identical for all $L / h$ ratios whereas maximum transverse displacement is in excellent agreement with that of the exact solution. The through thickness distribution of axial displacement $(L / h=4)$ is plotted in Fig. 5 . The FSDT and CBT underestimate the values of bending stress whereas they overestimate the transverse shear stress compared to those of the exact solution. It is also pointed out that, the bending and transverse stresses obtained using the FSDT and CBT are identical. The present theory and the theory of Reddy show excellent agreement for these stresses. The through thickness distributions of these stresses $\left(\bar{\sigma}_{x}, \bar{\tau}_{z x}\right)$ are shown in Fig. 6 and Fig.7.

\subsection{Bending analysis of simply supported three layered $\left(0^{\circ} /\right.$ core $\left./ 0^{\circ}\right)$ sandwich beams}

A three layered simply supported soft sandwich beam under sinusoidal load is analyzed using the following properties:

$$
\begin{aligned}
& 0^{0} \text { layer }(z=-0.5 h \text { to } z=-0.4 h): Q_{11}=25 \text { and } Q_{55}=0.5 \\
& \text { core }(z=-0.4 h \text { to } z=0.4 h): Q_{11}=4.0 \text { and } Q_{55}=0.06 \\
& 0^{0} \text { layer }(z=0.4 h \text { to } z=0.5 h): Q_{11}=25 \text { and } Q_{55}=0.5
\end{aligned}
$$

The thickness of each face sheet is $0.1 \mathrm{~h}$ and core is of $0.8 \mathrm{~h}$. The maximum displacements and stresses for $L / h=4,10,20,50$ and 100 are given in Table 4 . The exact elasticity solution for this problem is not available in the literature, therefore, the results are also generated by using the HSDT, FSDT and CBT. From Table 4 it is observed that the present theory is in excellent agreement with the HSDT of Reddy (1984) while predicting displacements and bending stress, but it predicts the lower value of transverse shear stress. The FSDT and CBT show identical values for axial displacement and bending stress for all $L / h$ ratios. The through thickness 
distributions of axial displacement, bending stress and transverse shear stress are plotted in Fig. 8 through Fig. 10.

\subsection{Bending analysis of simply supported five layered $\left(0^{\circ} / 90^{\circ} /\right.$ core $\left./ 90^{\circ} / 0^{\circ}\right)$ sandwich beams}

A simply supported five layered symmetric soft sandwich beam under sinusoidal load is considered with the following material properties:

$$
\begin{gathered}
0^{0} \text { layer }(z=-0.5 h \text { to } z=-0.45 h): Q_{11}=25 \text { and } Q_{55}=0.5 \\
90^{0} \text { layer }(z=-0.45 h \text { to } z=-0.4 h): Q_{11}=1.0 \text { and } Q_{55}=0.2 \\
\text { core }(z=-0.4 h \text { to } z=0.4 h): Q_{11}=4.0 \text { and } Q_{55}=0.06 \\
90^{0} \text { layer }(z=0.4 h \text { to } z=0.45 h): Q_{11}=1.0 \text { and } Q_{55}=0.2 \\
0^{0} \text { layer }(z=0.45 h \text { to } z=0.5 h): Q_{11}=25 \text { and } Q_{55}=0.5
\end{gathered}
$$

The thickness of each face sheet is $0.05 h$ and core is of $0.8 h$. The displacements and stresses obtained for different $L / h$ ratios are reported in Table 2. From this table, it is noted that the displacements and stresses evaluations using the present theory match with the HSDT of Reddy (1984) whereas the FSDT of Timoshenko (1921) and the CBT underestimate the displacements and bending stress. Fig. 11 through Fig. 13 shows through thickness distributions of axial displacement, bending stress and transverse shear stress for this loading case.

\begin{tabular}{|l|l|l|c|c|c|c|}
\hline$L / h$ & Theory & Model & $\bar{u}$ & $\bar{w}$ & $\bar{\sigma}_{x}$ & $\bar{\tau}_{z x}$ \\
\hline 4 & Present & RBT & 0.1271 & 1.429 & 0.9986 & 0.1893 \\
\hline & Reddy (1984) & HSDT & 0.1271 & 1.429 & 0.9986 & 0.1897 \\
\hline & Timoshenko (1921) & FSDT & 0.1238 & 1.430 & 0.9727 & 0.1910 \\
\hline & Bernoulli-Euler & CBT & 0.1238 & 1.232 & 0.9727 & 0.1910 \\
\hline & Ghugal (2006) & Exact & 0.1230 & 1.411 & 0.9958 & 0.1900 \\
\hline 10 & Present & RBT & 1.9434 & 1.264 & 6.1052 & 0.4767 \\
\hline & Reddy (1984) & HSDT & 1.9434 & 1.264 & 6.1050 & 0.4769 \\
\hline & Timoshenko (1921) & FSDT & 1.9351 & 1.264 & 6.0790 & 0.4774 \\
\hline & Bernoulli-Euler & CBT & 1.9351 & 1.232 & 6.0790 & 0.4774 \\
\hline & Ghugal (2006) & Exact & 1.9295 & 1.261 & 6.0910 & 0.4764 \\
\hline 20 & Present & RBT & 15.497 & 1.2398 & 24.343 & 0.9545 \\
\hline & Reddy (1984) & HSDT & 15.497 & 1.2398 & 24.343 & 0.9546 \\
\hline & Timoshenko (1921) & FSDT & 15.481 & 1.2398 & 24.317 & 0.9549 \\
\hline & Bernoulli-Euler & CBT & 15.481 & 1.2322 & 24.317 & 0.9549 \\
\hline & Ghugal (2006) & Exact & --- & 1.2318 & 24.194 & 0.9474 \\
\hline 50 & Present & RBT & 241.927 & 1.2331 & 152.007 & 2.3871 \\
\hline & Reddy (1984) & HSDT & 241.916 & 1.2331 & 152.004 & 2.3871 \\
\hline & Timoshenko (1921) & FSDT & 241.879 & 1.2331 & 151.977 & 2.3872 \\
\hline & Bernoulli-Euler & CBT & 241.886 & 1.2322 & 151.981 & 2.3872 \\
\hline 100 & Present & RBT & 1935.17 & 1.2322 & 607.953 & 4.7744 \\
\hline & Reddy (1984) & HSDT & 1935.79 & 1.2322 & 608.146 & 4.7761 \\
\hline & Timoshenko (1921) & FSDT & 1935.03 & 1.2322 & 607.909 & 4.7745 \\
\hline & Bernoulli-Euler & CBT & 1935.09 & 1.2322 & 607.927 & 4.7745 \\
\hline
\end{tabular}

Table 1. Comparison of displacements stresses for isotropic beam subjected sinusoidal load. 


\begin{tabular}{|c|c|c|c|c|c|c|}
\hline$L / h$ & Theory & Model & $\bar{u}$ & $\bar{w}$ & $\bar{\sigma}_{x}$ & $\bar{\tau}_{z x}$ \\
\hline \multirow[t]{5}{*}{4} & Present & RBT & 0.0171 & 4.4514 & 3.3593 & 0.2976 \\
\hline & Reddy (1984) & HSDT & 0.0171 & 4.4511 & 3.3592 & 0.2883 \\
\hline & Timoshenko (1921) & FSDT & 0.0142 & 4.7966 & 2.7905 & 0.2912 \\
\hline & Bernoulli-Euler & CBT & 0.0142 & 2.6254 & 2.7905 & 0.2947 \\
\hline & Pagano (1969) & Elasticity & 0.0153 & 4.7080 & 3.0019 & 0.2721 \\
\hline \multirow[t]{5}{*}{10} & Present & RBT & 0.2294 & 2.9225 & 18.019 & 0.7339 \\
\hline & Reddy (1984) & HSDT & 0.2294 & 2.9225 & 18.018 & 0.7263 \\
\hline & Timoshenko (1921) & FSDT & 0.2220 & 2.9728 & 17.440 & 0.7279 \\
\hline & Bernoulli-Euler & CBT & 0.2220 & 2.6254 & 17.440 & 0.7367 \\
\hline & Pagano (1969) & Elasticity & 0.2248 & 2.9611 & 17.653 & 0.7267 \\
\hline \multirow[t]{5}{*}{20} & Present & RBT & 1.7912 & 2.6999 & 70.342 & 1.4685 \\
\hline & Reddy (1984) & HSDT & 1.7912 & 2.6999 & 70.342 & 1.4550 \\
\hline & Timoshenko (1921) & FSDT & 1.7765 & 2.6978 & 69.762 & 1.4558 \\
\hline & Bernoulli-Euler & CBT & 1.7765 & 2.6254 & 69.762 & 1.4558 \\
\hline & Pagano (1969) & Elasticity & 1.7818 & 2.7094 & 69.973 & 1.4696 \\
\hline \multirow[t]{5}{*}{50} & Present & RBT & 27.794 & 2.6373 & 436.593 & 3.6694 \\
\hline & Reddy (1984) & HSDT & 27.794 & 2.6373 & 436.593 & 3.6393 \\
\hline & Timoshenko (1921) & FSDT & 27.757 & 2.6370 & 436.013 & 3.9396 \\
\hline & Bernoulli-Euler & CBT & 27.757 & 2.6254 & 436.013 & 3.6397 \\
\hline & Pagano (1969) & Elasticity & 27.766 & 2.6384 & 436.150 & 3.6849 \\
\hline \multirow[t]{5}{*}{100} & Present & RBT & 222.133 & 2.6284 & 1744.63 & 7.3382 \\
\hline & Reddy (1984) & HSDT & 222.133 & 2.6284 & 1744.63 & 7.2792 \\
\hline & Timoshenko (1921) & FSDT & 222.060 & 2.6283 & 1744.05 & 7.2793 \\
\hline & Bernoulli-Euler & CBT & 222.059 & 2.6254 & 1744.05 & 7.2798 \\
\hline & Pagano (1969) & Elasticity & 222.750 & 2.6366 & 1749.50 & 7.3963 \\
\hline
\end{tabular}

Table 2. Comparison of displacements stresses for two layered $\left(0^{0} / 90^{0}\right)$ laminated composite beam subjected sinusoidal load. 


\begin{tabular}{|c|c|c|c|c|c|c|}
\hline$L / h$ & Theory & Model & $\bar{u}$ & $\bar{w}$ & $\bar{\sigma}_{x}$ & $\bar{\tau}_{z x}$ \\
\hline \multirow[t]{5}{*}{4} & Present & RBT & 0.0086 & 2.6906 & 1.6934 & 0.1648 \\
\hline & Reddy (1984) & HSDT & 0.0086 & 2.7000 & 1.6989 & 0.1557 \\
\hline & Timoshenko (1921) & FSDT & 0.0051 & 2.4107 & 1.0085 & 0.1769 \\
\hline & Bernoulli-Euler & CBT & 0.0051 & 0.5109 & 1.0085 & 0.1769 \\
\hline & Pagano (1969) & Elasticity & 0.0092 & 3.0344 & 1.8820 & 0.1430 \\
\hline \multirow[t]{5}{*}{10} & Present & RBT & 0.0893 & 0.8744 & 7.0171 & 0.4353 \\
\hline & Reddy (1984) & HSDT & 0.0893 & 0.8751 & 7.0212 & 0.4334 \\
\hline & Timoshenko (1921) & FSDT & 0.0802 & 0.8149 & 6.3033 & 0.4422 \\
\hline & Bernoulli-Euler & $\mathrm{CBT}$ & 0.0802 & 0.5109 & 6.3033 & 0.4422 \\
\hline & Pagano (1969) & Elasticity & 0.0934 & 0.9357 & 7.6660 & 0.4230 \\
\hline \multirow[t]{5}{*}{20} & Present & RBT & 0.6604 & 0.6023 & 25.930 & 0.8797 \\
\hline & Reddy (1984) & HSDT & 0.6604 & 0.6025 & 25.935 & 0.8800 \\
\hline & Timoshenko (1921) & FSDT & 0.6420 & 0.5743 & 25.213 & 0.8845 \\
\hline & Bernoulli-Euler & CBT & 0.6420 & 0.5109 & 25.213 & 0.8801 \\
\hline & Pagano (1969) & Elasticity & 0.6695 & 0.6186 & 26.320 & 0.8740 \\
\hline \multirow[t]{5}{*}{50} & Present & RBT & 10.078 & 0.5256 & 158.298 & 2.2084 \\
\hline & Reddy (1984) & HSDT & 10.078 & 0.5256 & 158.308 & 2.2095 \\
\hline & Timoshenko (1921) & FSDT & 10.032 & 0.5211 & 157.584 & 2.2113 \\
\hline & Bernoulli-Euler & CBT & 10.032 & 0.5109 & 157.584 & 2.2002 \\
\hline & Pagano (1969) & Elasticity & 10.100 & 0.5283 & 158.700 & 2.2050 \\
\hline \multirow[t]{5}{*}{100} & Present & RBT & 80.349 & 0.5146 & 631.034 & 4.4194 \\
\hline & Reddy (1984) & HSDT & 80.349 & 0.5146 & 631.062 & 4.4217 \\
\hline & Timoshenko (1921) & FSDT & 80.257 & 0.5135 & 630.339 & 4.4226 \\
\hline & Bernoulli-Euler & CBT & 80.257 & 0.5109 & 630.339 & 4.4004 \\
\hline & Pagano (1969) & Elasticity & 80.400 & 0.5153 & 631.500 & 4.4150 \\
\hline
\end{tabular}

Table 3. Comparison of displacements stresses for three layered $\left(0^{0} / 90^{0} / 0^{0}\right)$ laminated composite beam subjected sinusoidal load. 


\begin{tabular}{|l|l|l|l|c|c|c|}
\hline$L / h$ & Theory & Model & $\bar{u}$ & $\bar{w}$ & $\bar{\sigma}_{x}$ & $\bar{\tau}_{z x}$ \\
\hline 4 & Present & RBT & 0.0183 & 9.8710 & 3.5920 & 0.1530 \\
\hline & Reddy (1984) & HSDT & 0.0183 & 9.8800 & 3.5920 & 0.1537 \\
\hline & Timoshenko (1921) & FSDT & 0.0087 & 5.1434 & 1.7067 & 0.1549 \\
\hline \multirow{2}{*}{10} & Bernoulli-Euler & CBT & 0.0087 & 0.8646 & 1.7067 & 0.1549 \\
\hline & Present & RBT & 0.1619 & 2.4086 & 12.714 & 0.3302 \\
\hline & Reddy (1984) & HSDT & 0.1615 & 2.4079 & 12.684 & 0.3707 \\
\hline & Timoshenko (1921) & FSDT & 0.1358 & 1.5492 & 10.666 & 0.3874 \\
\hline \multirow{2}{*}{20} & Bernoulli-Euler & CBT & 0.1358 & 0.8646 & 10.666 & 0.3874 \\
\hline & Present & RBT & 1.1421 & 1.2568 & 44.848 & 0.6514 \\
\hline & Reddy (1984) & HSDT & 1.1384 & 1.2543 & 44.705 & 0.7663 \\
\hline \multirow{2}{*}{50} & Timoshenko (1921) & FSDT & 1.0865 & 1.0358 & 42.667 & 0.7748 \\
\hline & Bernoulli-Euler & CBT & 1.0865 & 0.8646 & 42.667 & 0.7748 \\
\hline & Reddy (1984) & HSDT & 17.106 & 0.9272 & 268.715 & 1.9333 \\
\hline & Timoshenko (1921) & FSDT & 16.977 & 0.8920 & 266.673 & 1.9369 \\
\hline & Bernoulli-Euler & CBT & 16.977 & 0.8646 & 266.673 & 1.9369 \\
\hline 100 & Present & RBT & 136.55 & 0.8833 & 1072.50 & 3.2425 \\
\hline & Reddy (1984) & HSDT & 136.07 & 0.8803 & 1068.73 & 3.8722 \\
\hline & Timoshenko (1921) & FSDT & 135.81 & 0.8715 & 1066.70 & 3.8738 \\
\hline & Bernoulli-Euler & CBT & 135.81 & 0.8646 & 1066.70 & 3.8738 \\
\hline
\end{tabular}

Table 4. Comparison of displacements and stresses for three layered $\left(0^{0} / \mathrm{Core} / 0^{0}\right)$ sandwich beam subjected to sinusoidal load. 


\begin{tabular}{|l|l|l|l|c|c|c|}
\hline$L / h$ & Theory & Model & $\bar{u}$ & $\bar{w}$ & $\bar{\sigma}_{x}$ & $\bar{\tau}_{z x}$ \\
\hline 4 & Present & RBT & 0.0230 & 10.808 & 4.5109 & 0.1414 \\
\hline & Reddy (1984) & HSDT & 0.0230 & 10.815 & 4.5092 & 0.1453 \\
\hline & Timoshenko (1921) & FSDT & 0.0137 & 6.7293 & 2.6899 & 0.1580 \\
\hline 10 & Bernoulli-Euler & CBT & 0.0137 & 1.3627 & 2.6899 & 0.1580 \\
\hline & Present & RBT & 0.2394 & 2.9852 & 18.803 & 0.2765 \\
\hline & Reddy (1984) & HSDT & 0.2389 & 2.9834 & 18.761 & 0.3774 \\
\hline & Timoshenko (1921) & FSDT & 0.2140 & 2.2214 & 16.812 & 0.3950 \\
\hline & Bernoulli-Euler & CBT & 0.2140 & 1.3627 & 16.812 & 0.3950 \\
\hline & Present & RBT & 1.7674 & 1.7755 & 69.407 & 0.5293 \\
\hline & Reddy (1984) & HSDT & 1.7626 & 1.7721 & 69.218 & 0.7812 \\
\hline \multirow{2}{*}{50} & Timoshenko (1921) & FSDT & 1.7124 & 1.5774 & 67.248 & 0.7901 \\
\hline & Bernoulli-Euler & CBT & 1.7124 & 1.3627 & 67.248 & 0.7901 \\
\hline & Reddy (1984) & HSDT & 26.883 & 1.4284 & 422.28 & 1.9717 \\
\hline & Timoshenko (1921) & FSDT & 26.757 & 1.3971 & 420.30 & 1.9753 \\
\hline & Bernoulli-Euler & CBT & 26.757 & 1.3627 & 420.30 & 1.9753 \\
\hline \multirow{2}{*}{100} & Present & RBT & 214.93 & 1.3831 & 1688.09 & 2.6078 \\
\hline & Reddy (1984) & HSDT & 214.31 & 1.3792 & 1683.19 & 3.9489 \\
\hline & Timoshenko (1921) & FSDT & 214.05 & 1.3713 & 1681.21 & 3.9507 \\
\hline & Bernoulli-Euler & CBT & 214.05 & 1.3627 & 1681.21 & 3.9507 \\
\hline
\end{tabular}

Table 5. Comparison of displacements and stresses for five layered $\left(0^{0} / 90^{\circ} / \mathrm{Core} / 90^{0} / 0^{0}\right)$ sandwich beam subjected to sinusoidal load. 


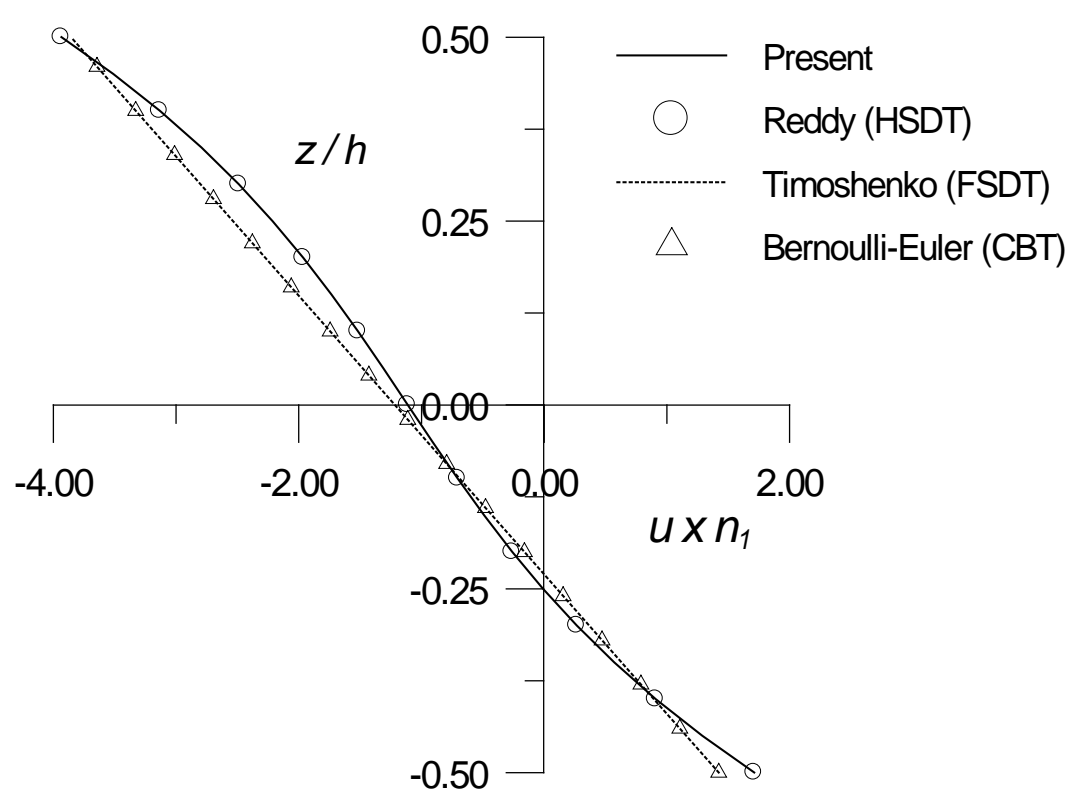

Fig. 2. Through thickness distribution of axial displacement $(\bar{u})$ for two layered $\left(0^{0} / 90^{0}\right)$ laminated composite beam subjected to sinusoidal load at $L / h=4$.

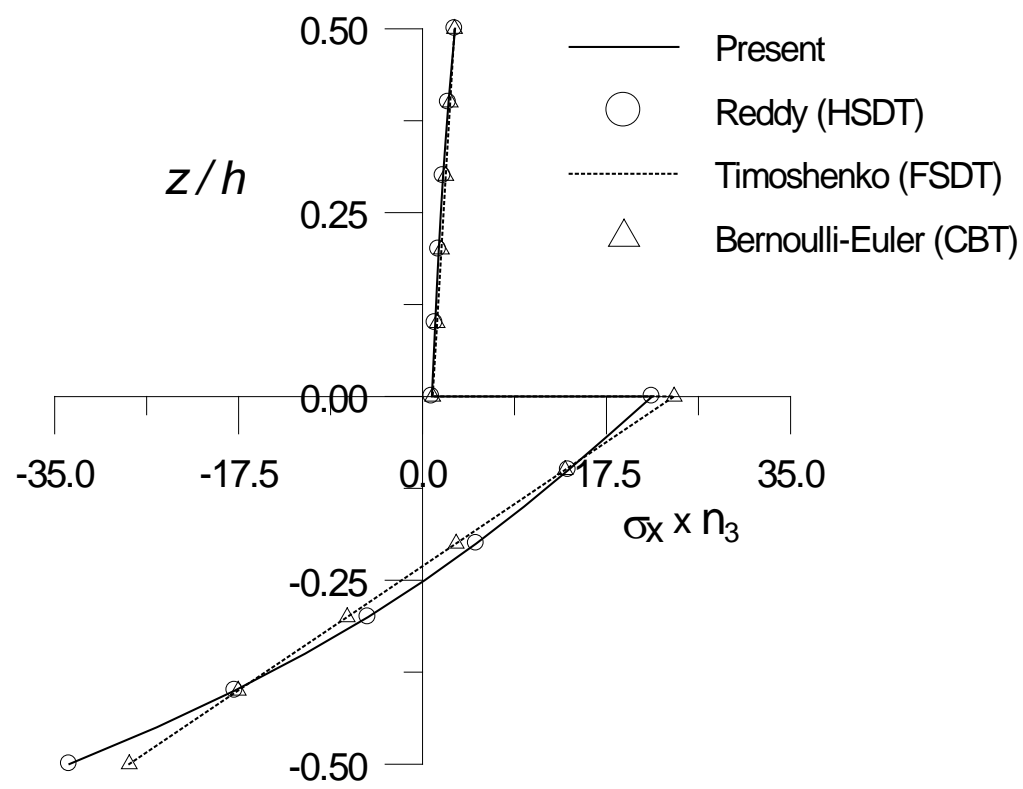

Fig. 3. Through thickness distribution of bending stress $\left(\bar{\sigma}_{x}\right)$ for two layered $\left(0^{0} / 90^{0}\right)$ laminated composite beam subjected to sinusoidal load at $L / h=4$. 


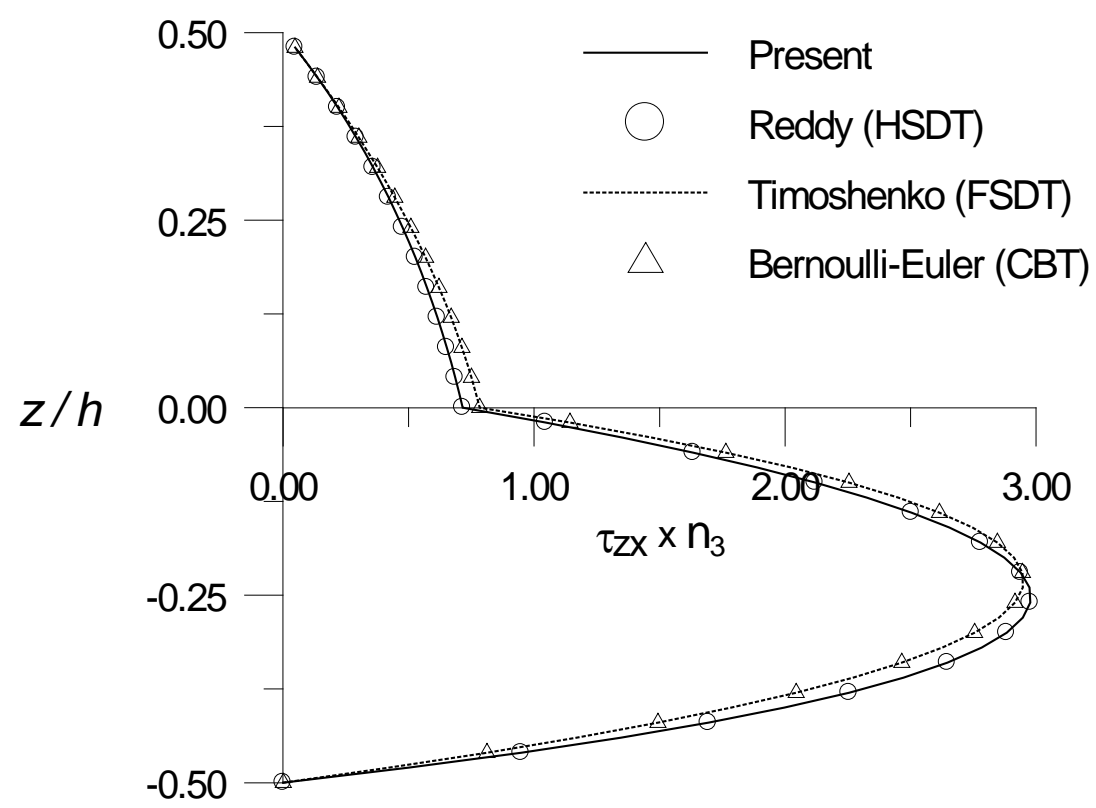

Fig. 4. Through thickness distribution of transverse shear stress $\left(\bar{\tau}_{z x}\right)$ for two layered $\left(0^{0} / 90^{0}\right)$ laminated composite beam subjected to sinusoidal load at $L / h=4$.

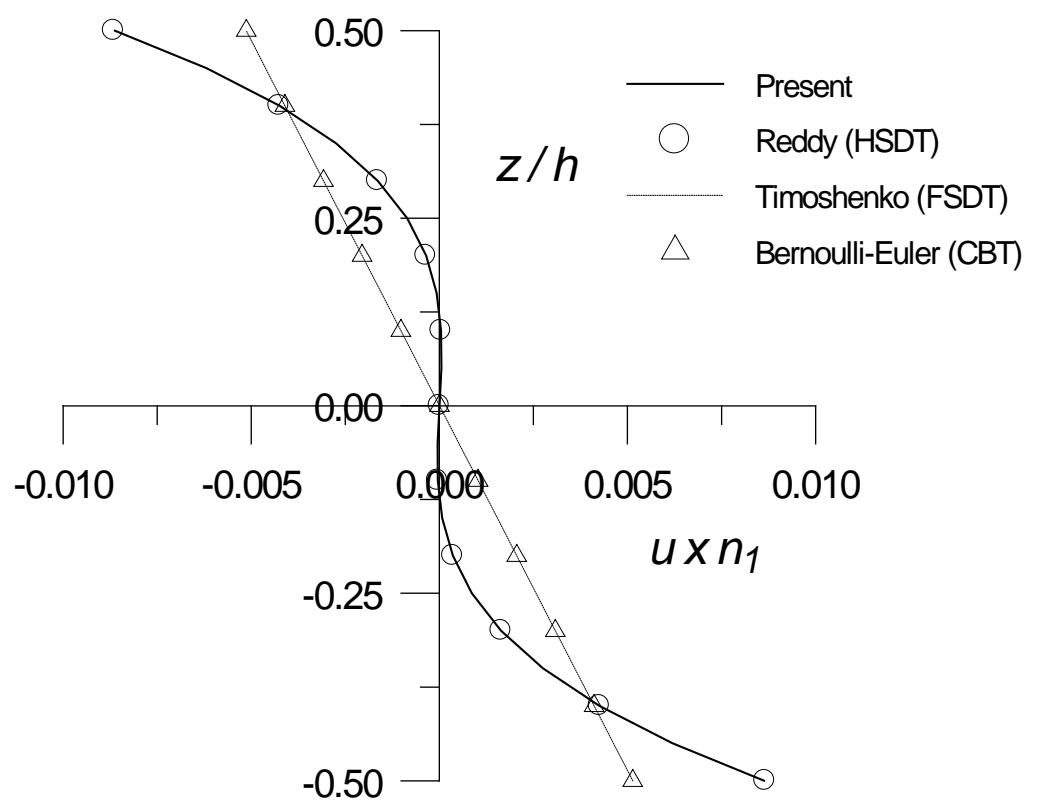

Fig. 5. Through thickness distribution of axial displacement $(\bar{u})$ for three layered $\left(0^{0} / 90^{0} / 0^{0}\right)$ laminated composite beam subjected to sinusoidal load at $L / h=4$. 


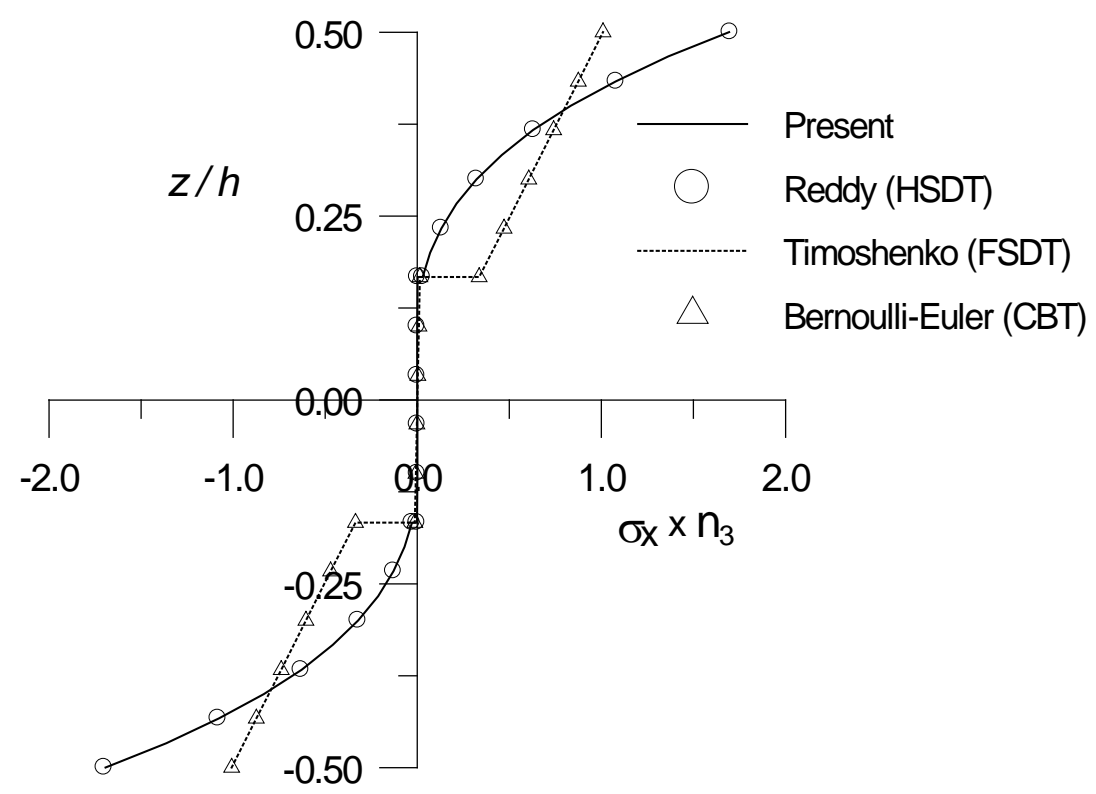

Fig. 6. Through thickness distribution of bending stress $\left(\bar{\sigma}_{x}\right)$ for three layered $\left(0^{0} / 90^{0} / 0^{0}\right)$ laminated composite beam subjected to sinusoidal load at $L / h=4$.

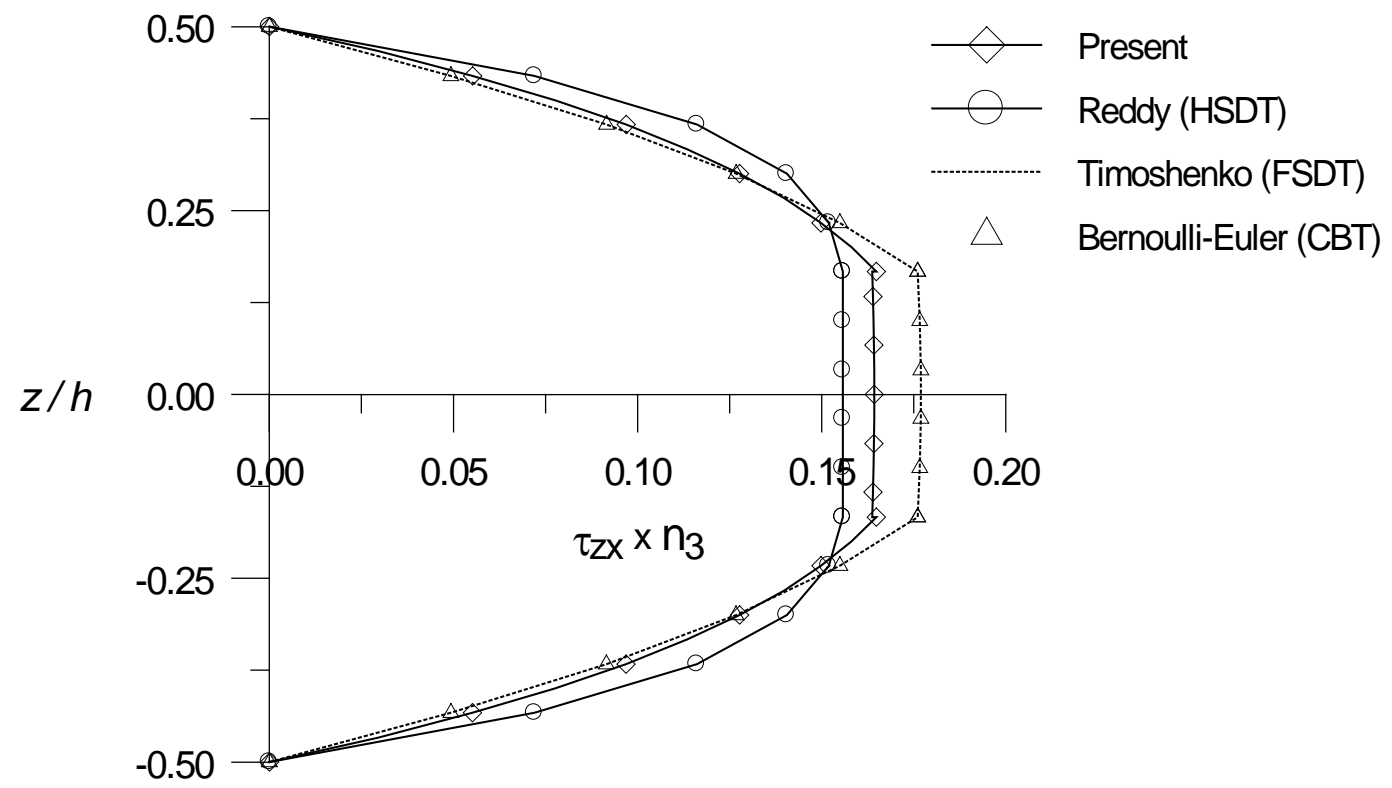

Fig. 7. Through thickness distribution of transverse shear stress $\left(\bar{\tau}_{z x}\right)$ for three layered $\left(0^{0} / 90^{0} / 0^{0}\right)$ laminated composite beam subjected to sinusoidal load at $L / h=4$. 


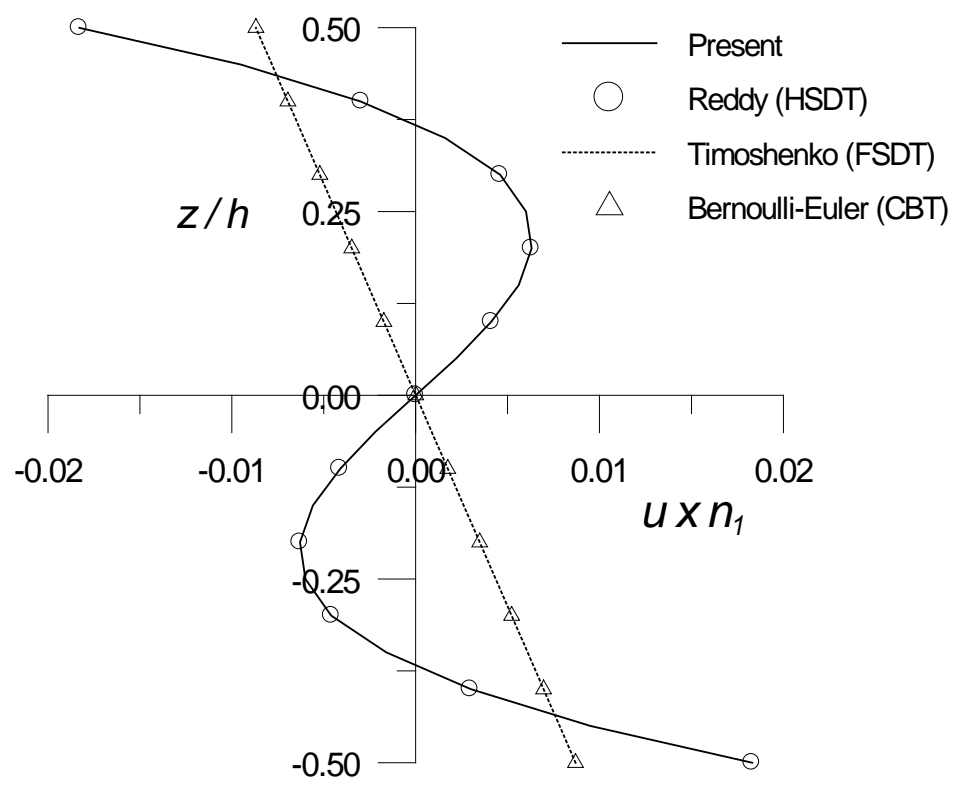

Fig. 8. Through thickness distribution of axial displacement $(\bar{u})$ for three layered $\left(0^{0} /\right.$ core $\left./ 0^{0}\right)$ sandwich beam subjected to sinusoidal load at $L / h=4$.

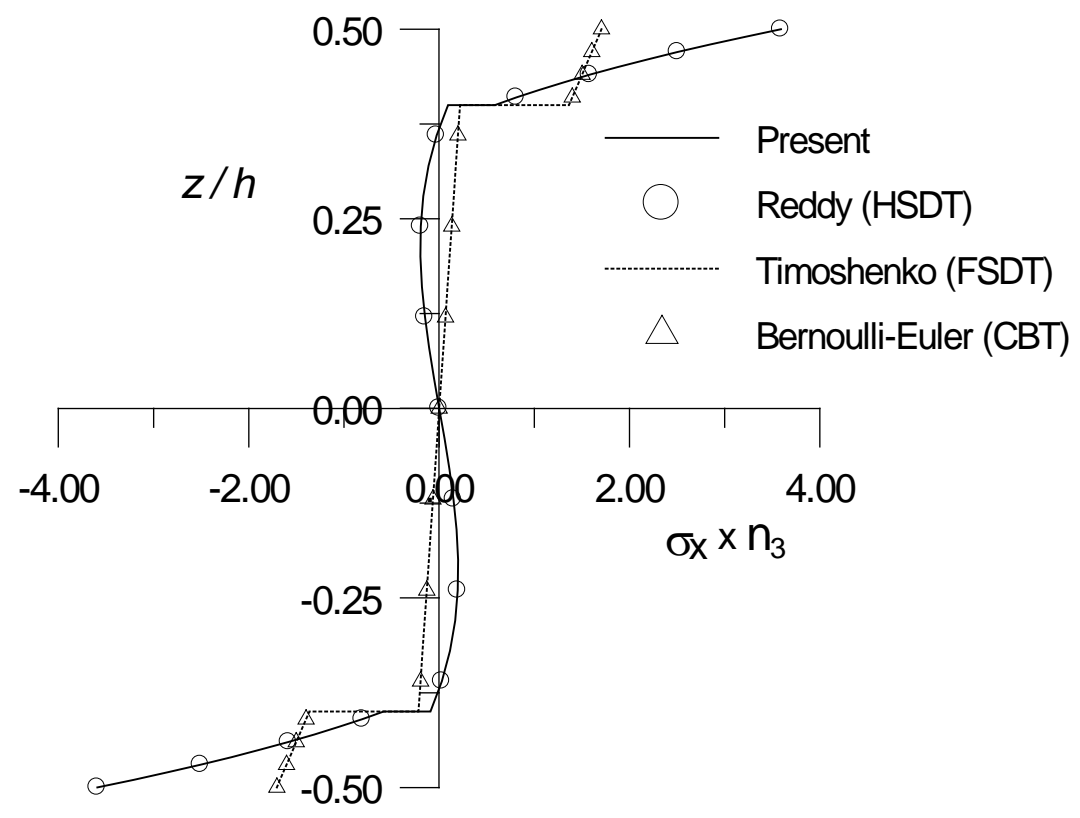

Fig. 9. Through thickness distribution of bending stress $\left(\bar{\sigma}_{x}\right)$ for three layered $\left(0^{0} /\right.$ core $\left./ 0^{0}\right)$ sandwich beam subjected to sinusoidal load at $L / h=4$. 


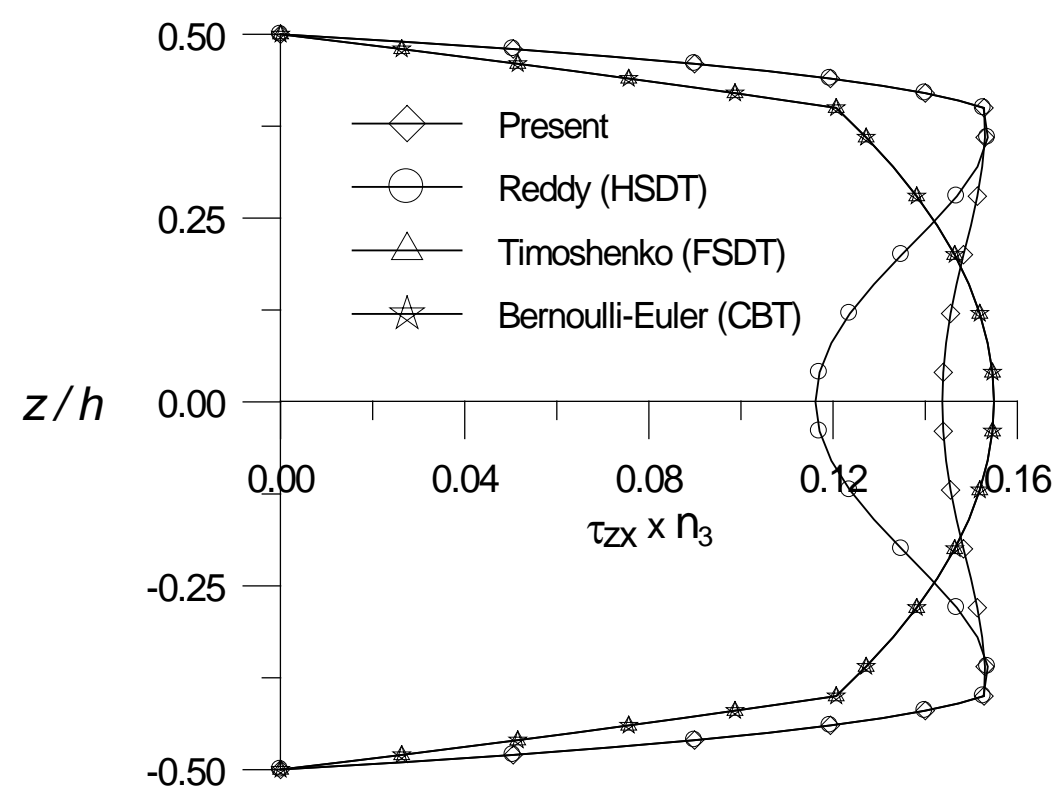

Fig. 10. Through thickness distribution of transverse shear stress $\left(\bar{\tau}_{z x}\right)$ for three layered $\left(0^{0} /\right.$ core $\left./ 0^{0}\right)$ sandwich beam subjected to sinusoidal load at $L / h=4$.

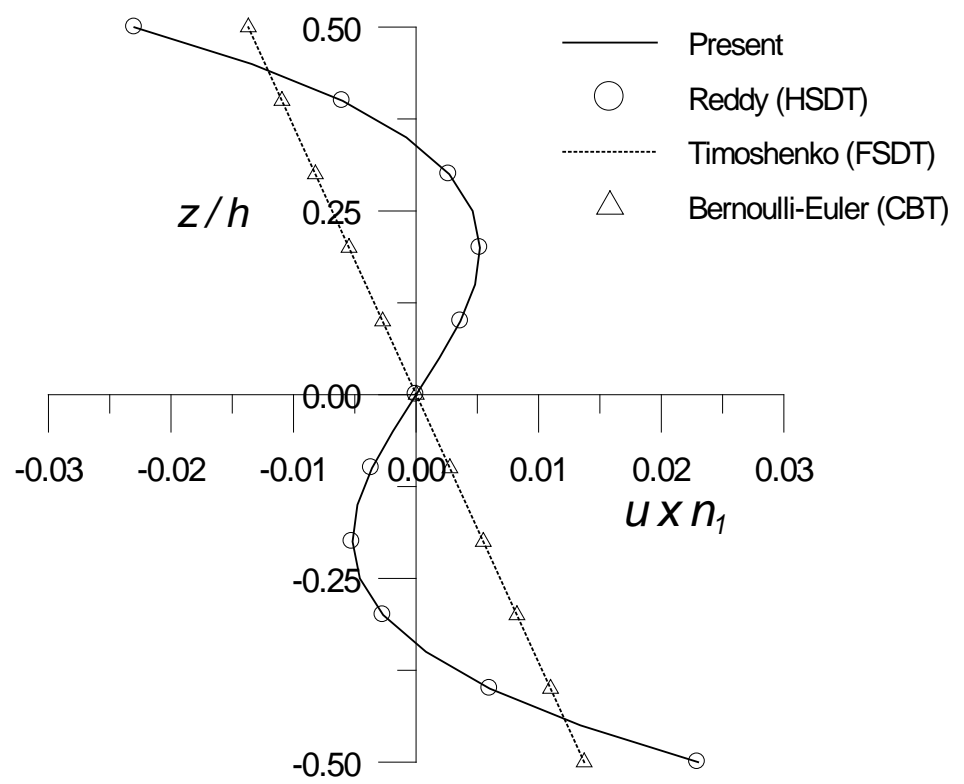

Fig. 11. Through thickness distribution of axial displacement $(\bar{u})$ for five layered $\left(0^{\circ} / 90^{\circ} /\right.$ core $\left./ 90^{\circ} / 0^{\circ}\right)$ sandwich beam subjected to sinusoidal load at $L / h=4$. 


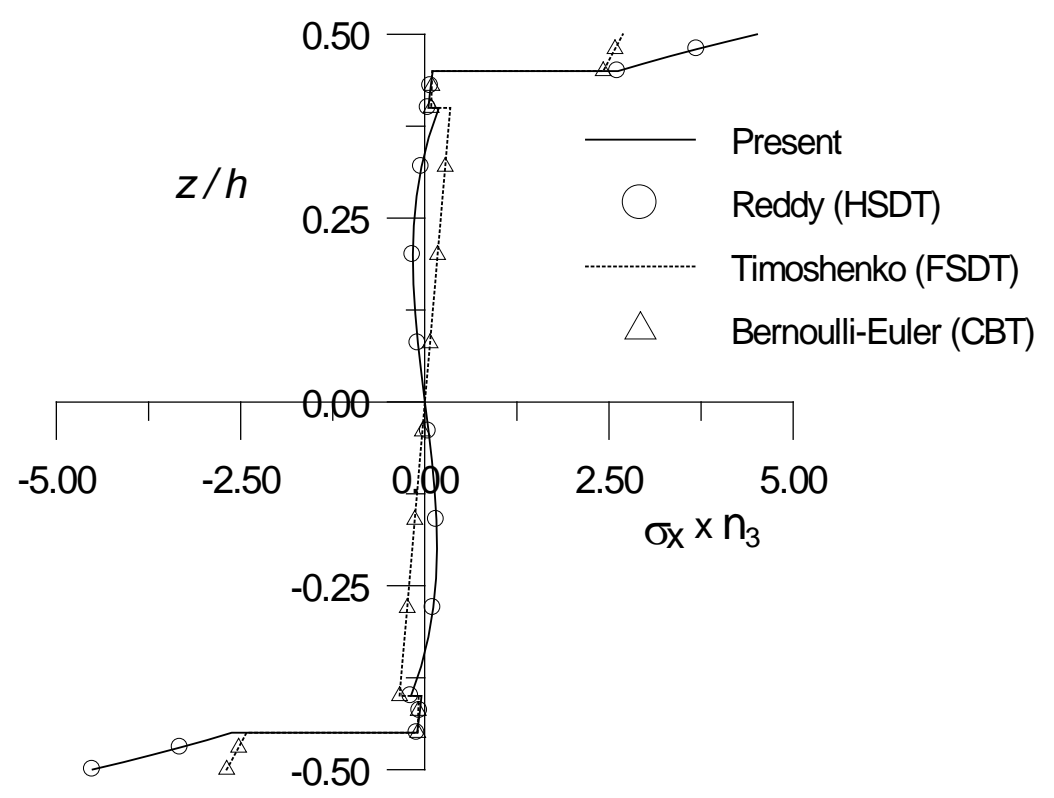

Fig. 12. Through thickness distribution of bending stress $\left(\bar{\sigma}_{x}\right)$ for five layered $\left(0^{0} / 90^{\circ} /\right.$ core $\left./ 90^{0} / 0^{0}\right)$ sandwich beam subjected to sinusoidal load at $L / h=4$.

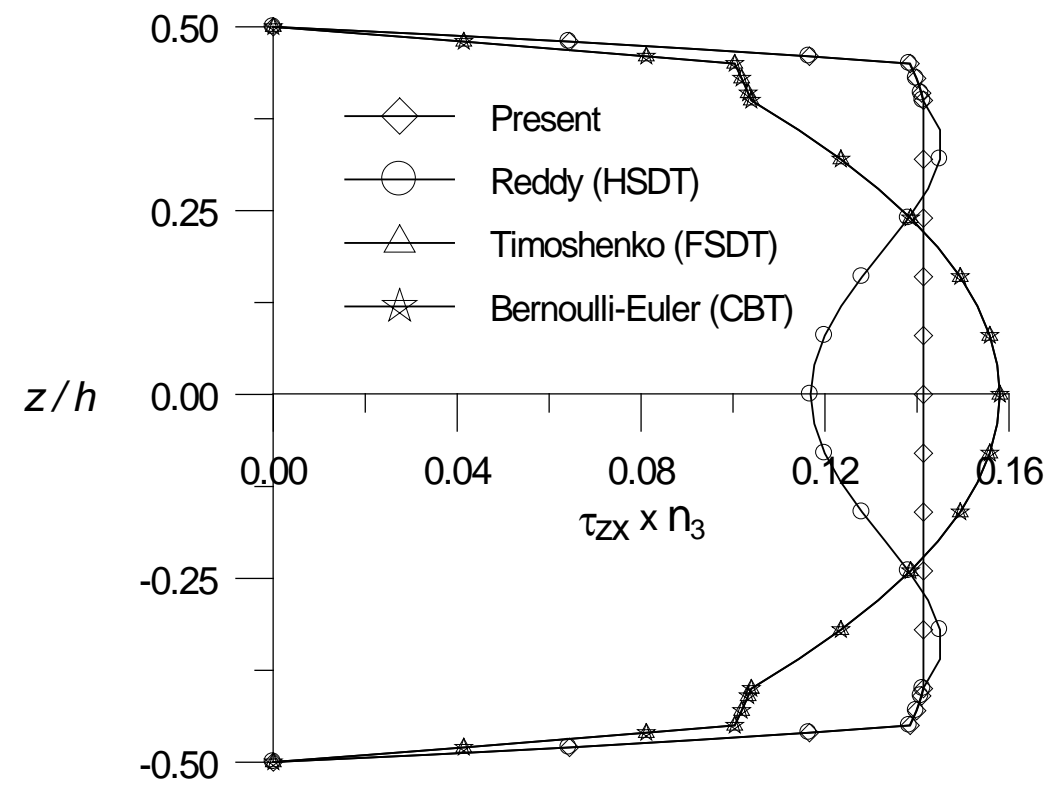

Fig. 13. Through thickness distribution of transverse shear stress $\left(\bar{\tau}_{z x}\right)$ for five layered $\left(0^{0} / 90^{\circ} /\right.$ core $\left./ 90^{0} / 0^{0}\right)$ sandwich beam subjected to sinusoidal load at $L / h=4$. 


\title{
5. Conclusions
}

In this paper, the refined beam theory has been applied for laminated composite and soft core sandwich beams. The mathematical formulation and application of the present theory to bending analysis of beams led to the following conclusions:

1. The theory satisfies the zero transverse shear conditions on top and bottom surfaces of the beam. The transverse stress continuity is satisfied using equilibrium equations of the theory of elasticity.

2. The governing equations and boundary conditions are variationally consistent.

3. The theory obviates the need of shear correction factors which are generally associated with the first order shear deformation theory.

4. The present results are in excellent agreement with those of the exact solution and the HSDT of Reddy.

5. The CBT and the FSDT show inaccurate results compared with the present theory and the HSDT of Reddy.

Извод

\section{Анализа напона код ламинарних композитних и сендвич греда са меким језгром уз помоһ теорие смичућег напона вишег реда}

\author{
A. S. Sayyad ${ }^{1} *$ Y. M. Ghugal ${ }^{1}$ and P. N. Shinde ${ }^{1}$ \\ ${ }^{1}$ Department of Civil Engineering, SRES's College of Engineering, Savitribai Phule Pune \\ University, Kopargaon-423601, Maharashtra, India \\ Email: attu_sayyad@yahoo.co.in \\ ${ }^{2}$ Department of Applied Mechanics, Government Engineering College, Karad-415124, \\ Maharashtra, India, \\ Email: ghugal@rediffmail.com \\ ${ }^{1}$ Department of Civil Engineering, SRES's College of Engineering, Savitribai Phule Pune \\ University, Kopargaon-423601, Maharashtra, India \\ Email: Pratap_60@yahoo.co.in \\ *главни aуmop attu_sayyad@yahoo.co.in
}

\section{Резиме}

У раду се испитује побољшана теорија греда (РБТ) у светлу савијања просто ослоњених изотропних, ламинарних композита и сендвич греда. Осно поље померања користи параболичну функцију за ординату дебљине како би се укључио ефекат трансверзалне смичуће деформације. Трансверзално померање састоји се од савијајућих и смичућих компоненти. Садашња теорија задовољава тангенциону компоненту напона горњих и доњих површина греде без узимања у обзир проблемског смичућег корективног фактора Тимошенка. Главне диференцијалне једначине и гранични услови везани за претпостављено поље померања добијене су по принципу виртуелног рада. Како би доказали веродостојност теорије, применили смо је на анализу савијања греда. Просто ослоњени изотропни, ламинарни композити и сендвич греде анализирани су путем Навије приступа. Нумерички резултати недимензионалних померања и напона добијени уз помоћ садашње теорије представљени су и упоређени са резултатима побољшаних теорија доступних у литератури заједно са решењем еластичности. 
Кључне речи: трансверзална смичућа деформација, смичући корективни фактор, трансверзални смичући напон, савијање, ламинарни композити, сендвич.

\section{References}

Aguiar RM, Moleiro F, Soares CMM (2012). Assessment of mixed and displacement-based models for static analysis of composite beams of different cross-sections, Composite Structures, 94, 601-616.

Carrera E, Giunta G (2010). Refined beam theories based on a unified formulation, International Journal of Applied Mechanics, 2(1), 117-143.

Chakrabarti A, Chalak HD, Iqbal MA, Sheikh AH (2011). A new FE model based on higher order zigzag theory for the analysis of laminated sandwich beam with soft core, Composite Structures, 93, 271-279.

Chalak, HD, Chakrabarti A, Iqbal, MA, Sheikh AH (2011). Vibration of laminated sandwich beams having soft core, Journal of Vibration and Control,18(10), 1422-1435.

Chen W, Wu Z (2005). A new higher-order shear deformation theory and refined beam element of composite laminates, Acta Mechanica Sinica, 21, 65-69.

Chen W, Li L, Xu, M (2011). A modified couple stress model for bending analysis of composite laminated beams with first order shear deformation, Composite Structures, 93, 2723-2732.

Gherlone M, Tessler A, Sciuva, MD (2011). A C ${ }^{0}$ beam elements based on the refined zigzag theory for multilayered composite and sandwich laminates, Composite Structures, 93, 28822894.

Ghugal YM (2006). A two-dimensional exact elasticity of thick isotropic beams, Departmental Report, No. 1, Department of Applied Mechanics, Government Engineering College, Aurangabad, India, 1-98.

Ghugal YM and Shinde SB (2013). Flexural analysis of cross-ply laminated beams using layerwise trigonometric shear deformation theory, Latin American Journal of Solids Structures, 10(4), 675-705.

Ghugal YM and Shmipi RP (2001). A review of refined shear deformation theories for isotropic and anisotropic laminated beams, Journal of Reinforced Plastics and Composites, 20(3), 255-272.

Kadoli R, Akhtar K, Ganesan N (2008). Static analysis of functionally graded beams using higher order shear deformation theory, Applied Mathematical Modeling, 32, 2509-2525.

Karama M, Afaq KS, and Mistou S (2008). A refinement of Ambartsumian multi-layer beam theory, Computers and Structures, 86, 839-849.

Lee J (2005). Flexural analysis of thin-walled composite beams using shear-deformable beam theory, Composite Structures, 70, 212-222.

Mechab I, Tounsi A, Benatta MA, Bedia, EAA (2008). Deformation of short composite beam using refined theories, Journal of Mathematical Analysis and Applications, 346, 468-479.

Pagano NJ (1969). Exact solutions for composite laminates in cylindrical bending, Composite Materials, 3, 398-411.

Reddy JN (2007). Nonlocal theories for bending, buckling and vibration of beams, International Journal of Engineering Sciences, 45, 288-307.

Reddy JN (1984). A simple higher order theory for laminated composite plates, ASME Journal of Applied Mechanics, 51, 745-752.

Sayyad AS, Ghugal YM (2011). Effect of transverse shear and transverse normal strain on bending analysis of cross-ply laminated beams, International Journal of Applied Mathematics and Mechanics, 7(12), 85-118.

Sayyad AS (2011). Comparison of various refined beam theories for the bending and free vibration analysis of thick beams, Applied Computational Mechanics, 5, 217-230. 
Sayyad AS, Ghugal YM, Borkar RR (2014). Flexural analysis of fibrous composite beams under various mechanical loadings using refined shear deformation theories, Composites: Mechanics, Computations, Applications. An International Journal, 5(1), 1-19.

Sayyad AS, Ghugal YM, Naik NS (2015). Bending analysis of laminated composite and sandwich beams according to refined trigonometric beam theory, Curved and Layered Structures, 2, 279-289.

Shimpi RP, Ghugal, YM (2001). A new layerwise trigonometric shear deformation theory for two-layered cross-ply beams, Composite Science and Technology, 61, 1271-1283.

Shimpi, RP, Patel HG (2006). A two variable refined plate theory for orthotropic plate analysis, International Journal of Solids and Structures, 43, 6783-6799.

Timoshenko SP (1921). On the Correction for Shear of the Differential Equation for Transverse Vibrations of Prismatic Bars, Philosophical Magazine, 41(6), 742-746.

Wang CM, Kitipornchai S, Lim CW (2008). Eisenberger M. Beam Bending Solutions Based on Nonlocal Timoshenko Beam Theory, ASCE Journal of Engineering Mechanics, 134, 475481. 